\section{Community based forest management and its impact on vegetation: a case study}

\begin{abstract}
Kumar PG ${ }^{(1)}$, Hate $S^{(2)}$, Chaturvedi $A^{(2)}$
The main focus of this case study was to reveal richness, uniqueness and economic importance of the minor forest producing species (MFPs). International Forest Resources and Institutions (IFRI) techniques were used to collect biophysical information pertaining to forest, vegetation and socio economy of dwellers. Ninety plots were demarcated to represent all types of vegetation and linked to social and institutional parameters. The regeneration status of the plant species was correlated to different resource utilization management practices, which includes harvesting practices as well as associated anthropogenic disturbances. The present paper tries to relate the usage of minor forest produces and its reflection on richness and diversity of the ecosystem. With above objects in mind, this paper brings out the role of community forest management and its impact on vegetation and sustainable development of aboriginals based on successive field work from three villages, Markegaon, Devulgaon and Ranvahi of Gadchiroli district of Maharashtra, India. An attempt has been made to develop a model for sustainable development and management of minor forest producing species.
\end{abstract}

Keywords: Sustainable development, Minor forest produces, Conservation of biodiversity, Community forestry, Forest analysis

\section{Introduction}

Conservation of biodiversity and sustainable development of any ecosystem is a multifaceted activity. It includes various components, including, biological, ecological and the issue of enterprise. These components become active and very obvious, when one finds dependence of human being on their surrounding vegetation more than the others. Successful co-existence of the plant and man is a tricky situation. Although of man has fulfilled basic needs through the plants, which they find in their surrounding they in turn jeopardize the health of their green wealth. Biodiversity is a part of our daily life and livelihood; and constitutes the resources upon which families, communities, nations and future generations depend (Dowdeswell 1995). Many minor forest pro-

(1) Defence Institute of High Altitude Research, Defence R\&D Organisation, Govt. of India, Leh - Ladakh, India, c/o 56 APO, 194101; (2) Department of Botany, R.T.M. Nagpur University, Nagpur, India.

(a) Phani G. Kumar

(phani_bot@rediffmail.com)

Received: Oct 16, 2008 - Accepted: Jan 09, 2009

Citation: Kumar PG, Hate S, Chaturvedi A, 2009. Community based forest management and its impact on vegetation: a case study. iForest 2: 93-98 [online: 2009-06-10] URL: http://www.sisef.it/iforest/show.php? id $=490$ duces (MFP's) are important not only in rural and tribal economies, but also in the national economy (Appasamy 1993, Hegde et al. 1996, Kalla 1988, Sekar et al. 1996, Shiva \& Mathur 1995). Humans depend on MFP's for food, energy, construction materials, medicine and much else besides. Further, these resources have the critical character of being renewable, hence with proper management they can be used sustainably (McNeely 1988), ensuring their use for our future generations.

India is very rich in biodiversity at ecosystems and species level, it ranks sixth among 12 mega-diversities in the world and holds two biodiversity "hot spots". India possesses 49,219 species of flora about $15 \%$ of global known plant species (Sinha \& Bawa 2002). Gadchiroli, a declared backward district in a highly developed state of Maharashtra (India), has a major share of the forest area and also of tribal population (including primitive tribes). Out of its total geographical area of $14,412 \mathrm{~km}^{2}, 93.06 \%$ is classified as "forest" with 38 per cent of its population as "tribal". Almost 64 percent of the state's "protected forest", where the local communities have comparatively more rights belong to Gadchiroli district. The study becomes relevant because little more than two decades ago, this area, which was once known for high quality forest, was found to be degrading. Under the $74^{\text {th }}$ amendment to the Indian constitution, management rights of 14 items of minor forest produce have been transferred to the local Gram Sabha in scheduled areas, and Gadchiroli is one of them. Detailed field study was restricted to Dhanora (Markegaon and Devulgaon) and Khurkhera (Ranvahi) sub divisions of Gadchiroli district. All these three villages fall under same biogeoclimatic zone, but differ in their resource utilization practices. Residents of forest villages, experiencing the brunt of reduced availability of basic forest products like fuel wood and fodder, have now decided to revive their age-old management practices and conservation methods. Its preliminary impact on the quality of forest is found remarkable. The present paper tries to relate the usage and management of minor forest produces in consonance to richness and diversity of the vegetation

\section{Materials and methods}

International Forest Resources and Institutions (IFRI) method was used to collect biophysical information of the forest, vegetation and socio-economy of the dwellers (IFRI 2002). In this method information was collected through pre-structured research questionnaire/forms as given below:

1. Forest form: It included details of geological distribution of the forest, history of the settlement, harvesting methods, soil structure, pest information, anthropogenic disturbances etc.

2. Village form: It included information regarding community structure, population, literacy rate, cultivation practices, socioeconomy etc.

3. User group form: Information on the institutional aspects like rules in-use, sanctions, use of forest resource, details of user groups, marketing information etc. was collected through this form.

4. Plot form: It was used to collect vegetation data of the forest and served as key link between the social and institutional data collected in other forms.

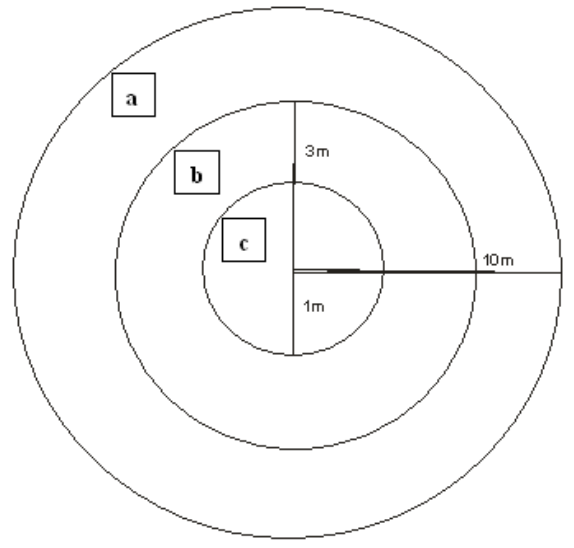

Fig. 1 - Methodology adopted for forest vegetation analysis. (a): $10 \mathrm{~m}$ radius; (b): $3 \mathrm{~m}$ radius; (c): $1 \mathrm{~m}$ radius. 
Tab. 1 - Socio-physical parameters of the villages studied.

\begin{tabular}{|c|c|c|c|}
\hline Parameters & Markegaon & Devulgaon & Ranvahi \\
\hline Latitude & N 20 $14^{\prime} 42.3$ & N 2030’ 33.2 & $\mathrm{~N} 21^{\circ} 37^{\prime} 21.1$ \\
\hline Longitude & E $80^{\circ} 19^{\prime} 59.6$ & E $80^{\circ} 20^{\prime} 53.5$ & $\mathrm{E} 79^{\circ} 13^{\prime} 1.0$ \\
\hline Altitude (msl) & $262-376$ & $214-276$ & $257-358$ \\
\hline Forest area (hectare) & 469.44 & 601.37 & 643.51 \\
\hline Population & 161 & 173 & 393 \\
\hline $\begin{array}{l}\text { Adults } \\
(\text { male }+ \text { female })\end{array}$ & $58+55$ & $53+62$ & $137+140$ \\
\hline $\begin{array}{l}\text { Children } \\
\text { (male + female) }\end{array}$ & $24+24$ & $34+24$ & $56+60$ \\
\hline $\begin{array}{l}\text { Number of } \\
\text { Households }\end{array}$ & 32 & 33 & 81 \\
\hline Average Family size & 5 & 5 & 5 \\
\hline Literacy percent & 50.9 & 50.8 & 74.5 \\
\hline $\begin{array}{l}\text { Per capita forest } \\
\text { (hectare) }\end{array}$ & 2.91 & 3.47 & 1.63 \\
\hline Primary education & 64 & 11 & 110 \\
\hline Houses & $\begin{array}{l}\text { Mud brick with tiled } \\
\text { or thatched roofs }\end{array}$ & $\begin{array}{l}\text { Mud brick with tiled } \\
\text { or thatched roofs }\end{array}$ & $\begin{array}{l}\text { Mud brick with tiled or } \\
\text { thatched roofs; very few } \\
\text { hoses with cement slabs. }\end{array}$ \\
\hline Crops grown & $\begin{array}{l}\text { Paddy, pigeon pea, } \\
\text { Mung bean, urd bean } \\
\text { and french bean }\end{array}$ & $\begin{array}{l}\text { Paddy, pigeon pea, } \\
\text { grass pea, gram and } \\
\text { linseed }\end{array}$ & $\begin{array}{l}\text { Paddy, Chilli, turi, grass } \\
\text { pea, gram and linseed }\end{array}$ \\
\hline
\end{tabular}

These plots were selected randomly to record the anthropogenic impact of forest use. Each plot had three circles of 1 meter, 3 meters and 10 meters radius each, and smaller plots were nested in larger ones (Fig. 1). Plots of one meter radius were drawn to observe annual vegetation and seedlings, three meter radius plots were drawn for shrubs and saplings of 2.5 to $10 \mathrm{~cm}$ dbh (diameter at breast height) and plots of ten meter radius were drawn for the study of trees $(\leq 10 \mathrm{~cm}$ $\mathrm{dbh}$ ) and woody climbers. A total 90 plots (i.e., $90 \times 3$ nested plots of $1 \mathrm{~m}, 3 \mathrm{~m}$ and $10 \mathrm{~m}$ ) were demarcated to represent all types of vegetation in the forests of villages Markegaon, Devulgaon and Ranvahi. A floristic survey was done in all ninety plots to compare diversity of the species. Plant species were identified with the help of The Flora of British India (Hooker 1904), The Flora of the Presidency of Bombay (Cooke 1958), and The Flora of Nagpur district (Ugemuge 1978).

Vegetation data were quantitatively analysed for density, frequency, and abundance (Misra 1968). Relative density, relative frequency and relative dominance were determined following Phillips (1959). The important value index (IVI) was determined as sum of relative density, relative frequency and relative abundance (Curtis 1959). The species richness, diversity index $(\mathrm{H})$ and concentration of dominance $(\mathrm{Cd})$ of the species in the forest were also analysed. The diversity index was calculated following Shannon \& Wiener (1963) method as:

$$
\bar{H}=-\sum\left(N_{i} / N\right) \log _{2}\left(N_{i} / N\right)
$$

The concentration of dominance was determined using the Simpson's index (Simpson 1949) as:

$$
C d=\sum\left(N_{i} / N\right)^{2}
$$

where $N_{\mathrm{i}}$ is number of individual species and $N$ is a total number of all species present in the forest.

\section{Results}

Three villages, Markegaon, Devulgaon and Ranvahi fall under the same bioclimatic zone. All these forests belong to the dry deciduous category and receive around 1420 $\mathrm{mm}$ of rainfall annually. The soil types and conditions do not vary much among the three forests, only from loam to silty-sandy-clayloam in Markegaon, from sandy-loam to significant. silty-clay-loam in Devulgaon and from sandy-silty-loam to clay in Ranvahi. The soil was found to be uniformly shallow and severely pest-infested in all the forests. Socio-physical parameters of the three villages are tabulated in Tab. 1. Results of floristic survey showed that Markegaon was with largest number of species (113 plant species belonging to 91 genera) followed by Devulgaon (104 plant species belonging to 79 genera) and Ranvahi (78 plant species belonging to 69 genera). In Devulgaon, tree species number was reduced from saplings to older trees; however, in other two villages some disturbances were observed in the seedlings and saplings. DBH and height analysis of the trees species in studied forests have been depicted in Fig. 2.

Analysis of variance with Dunnet multiple comparison test showed Devulgaon has highly dense and abundant forest vegetation as compared to Markegaon (0.02 and 0.28 respectively) and Ranvahi ( 0.11 and 0.02 respectively). Differences between frequency, density and abundance of all these three forests are presented in Tab. 2, and important value of each species (IVI) of major vegetation under study is given in Fig. 3. Analysis of diversity indices showed that Devulgaon has an increasing species richness from saplings (2.456) to trees (2.876) and to seedlings (3.599), being the concentration of dominance in the same line. Diversity indices (Shannon's and Simpson's index) are tabulated in Tab. 3.

Dependence of the people on various minor forest products in these villages was found to be very high. Several minor forest produces are being used by aboriginals for their dayto-day needs and many of them are their income generative sources. It was observed that consumption of Bamboo (Bambusa arundinaceae) is very high, being used for making many items like baskets, rope holder, grain covers, shelves, poultry hatchery, roofing of house, pig sty, livestock room, fencing, etc. There are several other items which tribal people use in their day-to-day

Tab. 2 - Frequency, density and abundance of the vegetation: comparative analysis of the forests under study. $\left({ }^{*}\right)$ : ANOVA with Dunnet Multivariate Comparison test; P > 0.05: non

\begin{tabular}{llccc}
\hline \multirow{2}{*}{ Forest } & Parameters & $\begin{array}{c}\text { Mean } \\
\text { difference* }\end{array}$ & \multicolumn{2}{c}{ 95\% confidence interval } \\
\cline { 4 - 5 } Devulgaon -Markegaon & Frequency & 2.00 & -9.92 & Upper \\
& Density & 0.02 & -0.50 & 13.92 \\
& Abundance & 0.28 & -0.42 & 0.46 \\
& Frequency & 1.66 & -10.25 & 0.99 \\
\hline Devulgaon -Ranvahi & Density & 0.11 & -0.37 & 13.59 \\
& Abundance & 0.02 & -0.73 & 0.59 \\
& Frequency & 0.33 & -11.59 & 0.69 \\
\hline Markegaon - Ranvahi & Density & 0.13 & -0.35 & 12.26 \\
& Abundance & 0.30 & -0.41 & 0.61 \\
& & &
\end{tabular}



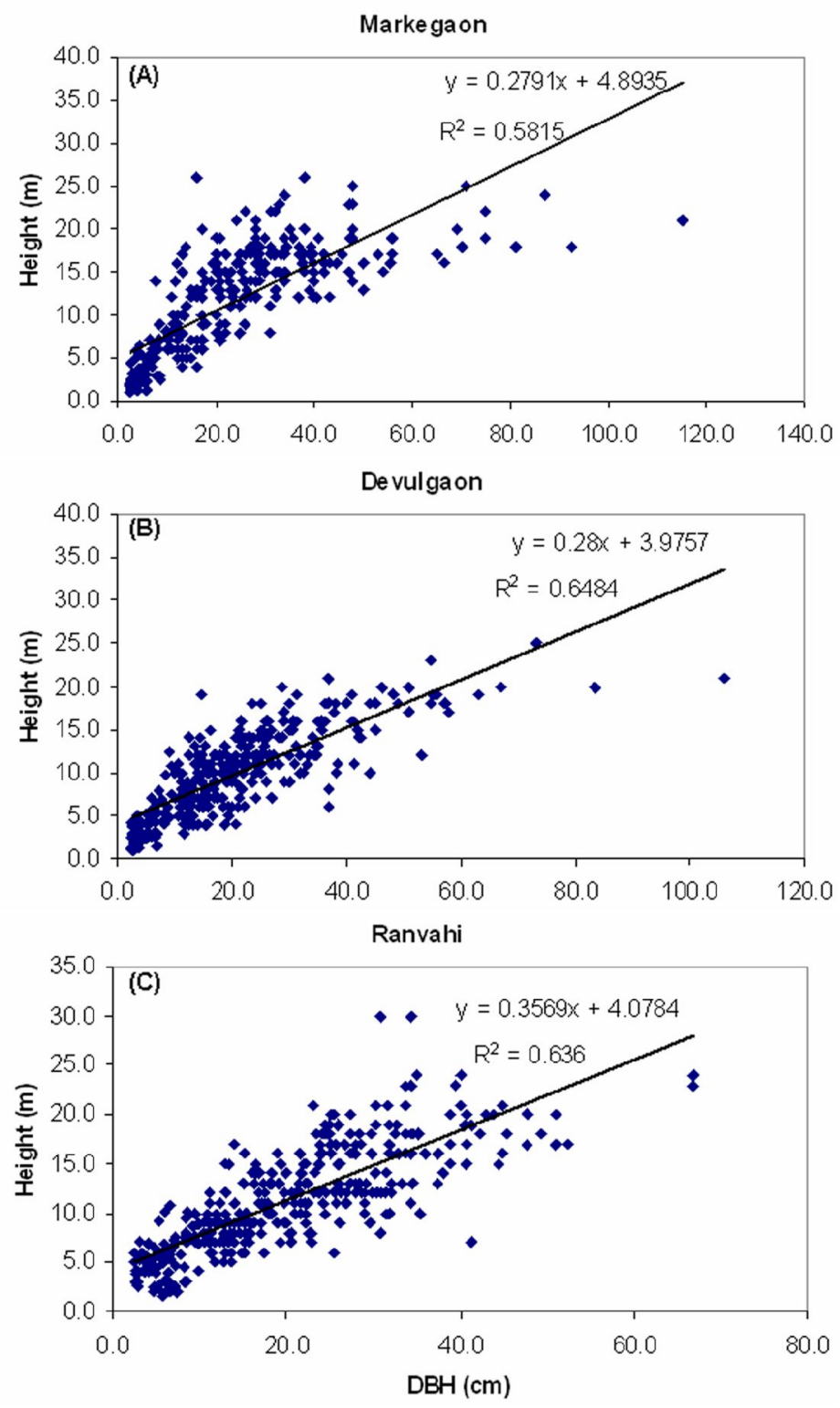

Fig. 2 - Diameter at breast height (dbh) and height analysis of vegetation under study. (a): Markegaon; (b): Devulgaon; (c): Ranvahi.

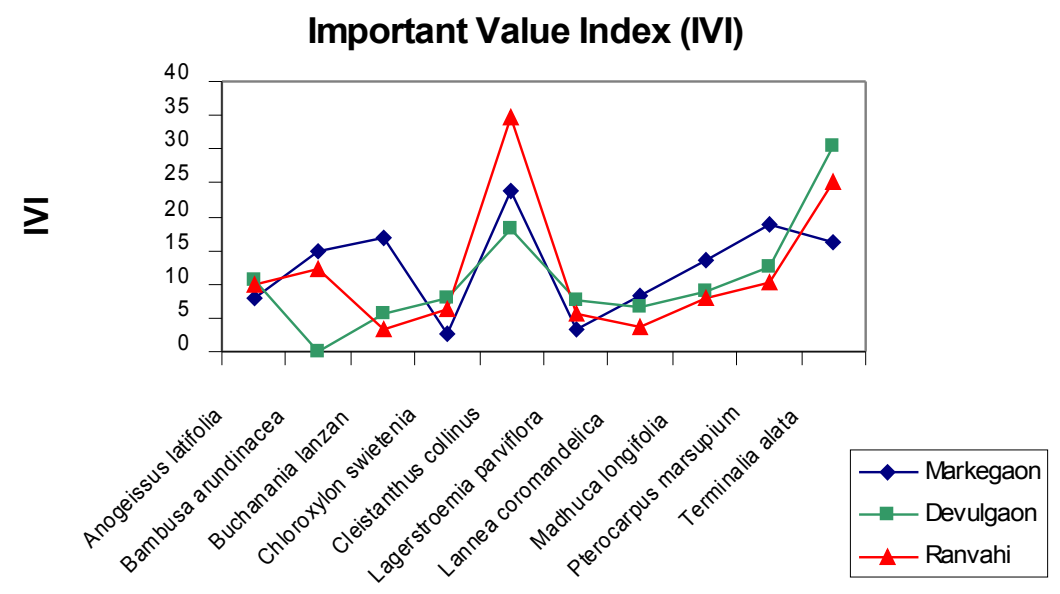

Fig. 3 - Important value index of major vegetation under study. life and are made from forest products, like grain crusher from the wood of Acacia catechu Willd. (Khair) and Soymida febrifuga Juss.(Rohan), lamp stand are made out of Terminalia alata, mats are woven from the grass blades of Borassus flabellifer $\mathrm{L}$. (Sindhi), thin ropes are made out of Hibiscus cannabinus L. (Ambardi) bark, Cyperus rotundus L. and Helicteres isora L. (Murad sheng), from the leaves of Azadirachta indica Juss. (Kaduneem) and Cleistanthus collinus pesticides for crops. Most of the fallen branches and leaves of the forest species are being used as fuel and fodder. However, some times they cut the branches for their daily needs, an average quantity of fuel wood used per day is $5 \mathrm{Kg}$ (fallen branches) per house. Different minor forest produces, uses and the product value are tabulated in Tab. 4 .

\section{Discussion}

\section{Institutional analysis}

Common aspects in these three villages are the geographical location, topography, erstwhile plant species, legal status of forest, main occupation of the people, and the state of forests some 25 years ago. Differences are the degree of heterogeneity, size (though the differences are not very large), per capita forest land available and difference in priorities taken as proxy to discount rate which is also reflected in their concept of wealth (Tab. 1). Many of minor forest produces (MFP's) are being used by locals for the improvement of their livelihood status; these includes leaves, flowers, fruits, branches, gums/resins, roots, fallen and dead wood (Lynch \& Alcorn 1994). Factors like total forested area, access, historic use of both target and non-target species and observation of land use patterns in adjacent areas have a dramatic impact on the forest development, which contributes to supply and the sustainable use (Howard 1993). If the harvesting quotas, established based on the original total area, continue despite reductions in supply area, harvesting per unit area will exceed growth and yield, leading to depletion of the target species (Boot \& Gullison 1995). Earlier Markegaon forest was well managed hence maximum girth rate of the vegetation with more number of older trees was found, however, in recent times it was disturbed. As for Devulgaon, being maintained by management practices since 15 years ago, the forest analysis has shown maximum count of seedlings and saplings. Ranvahi village was neither maintained nor being maintained by any sort of management practices hence its dbh classes showed huge variation (Fig. 2).

\section{Vegetation analysis}

Forest vegetation was measured by few parameters, including the number of species 
present (species richness), their relative abundances (species evenness), the particular species present (species composition), the interactions among species (impact factor), temporal and spatial variation in these properties (Ghate et al. 2003, Chaturvedi et al. 2006). Comparative analysis (relative frequency, relative density and relative abundance) of these species with other forest species showed Cleistanthus collinus to be dominant with high IVI in two of the forests (Markegaon and Ranvahi) and Terminalia alata in Devulgaon (Tab. 3). Anogeisus latifolia (DC.) Wall. (Dhawra), Madhuca longifolia (Koen.) Macbr (Mohwa) and Lannea coromandelica (Houtt.) Merr. (Mahaiw) showed random distribution in all the three villages. According to Odum (1971), clumped (contagious) distribution is the most common pattern in nature, while random distribution is expected in uniform environments.

Species diversity is considered as an important ecological attribute of a natural and organized community (Hariston 1964) and has functional consequences because of the number and kinds of species present and their influence on ecosystem process (Lavorel et al. 1999). In the present study, both species richness and concentration of dominance was observed to increase from trees to saplings to seedlings in Devulgaon (Tab. 3). This is an indication of good forest condition at the present time and for future generations. Markegaon showed an increasing pattern of these indices from trees to saplings, but maintained minimal difference from seedling to saplings; it seems that this forest is in climax succession stage. Whereas, Ranvahi forest showed growth disturbances, hence trees with maximum richness but seedlings and saplings with less richness (Tab. 3). The people of Ranvahi used to clear the ground either by fire or by cutting ground flora before harvest of Madhuca longifolia flowering (to make alcoholic beverage) and Diospyros melanoxylon leaf collection (to prepare cigar like item). Hence the regeneration of ground flora and tree species got down. The regeneration status of species harvested for MFP's as inferred from population structure is a useful indicator of whether MFP harvest is likely to be detrimental to the target population in the long term (Hall \& Bawa 1993, Chaturvedi \& Kumar 2005)

\section{Role of community}

The achievement of Devulgaon community is outstanding especially for the management of forest harvesting, felling of trees and grazing, etc. Main reason for the success is found to be the effective leadership provided by few persons within the community and collective action. Forest vegetation is considered as an important ecological attribute
Tab. 3 - Diversity indices of the forests under study: species richness (Shannon index) and concentration of dominance (Simpson index).

\begin{tabular}{lccc}
\hline \multicolumn{1}{c}{$\begin{array}{c}\text { Shannon } \\
\text { index }\end{array}$} & Markegoan & Devulgaon & Ranvai \\
\hline Seedlings & 2.664 & 3.402 & 1.756 \\
Saplings & 2.667 & 2.876 & 1.956 \\
Trees & 2.501 & 2.357 & 2.337 \\
\hline \multicolumn{1}{c}{ Simpson $\quad$ index } & Markegoan & Devulgaon & Ranvai \\
\multicolumn{1}{c}{ Seedlings } & 0.182 & 0.506 & 0.332 \\
Saplings & 0.187 & 0.184 & 0.132 \\
Trees & 0.112 & 0.100 & 0.070 \\
\hline
\end{tabular}

Tab. 4 - Minor forest produces with source, uses and income generation $(\mathrm{Rs}=\mathrm{Rupia}$, Indian currency; 1 US\$ $=47$ Rs). Local names are in parentheses.

\begin{tabular}{|c|c|c|}
\hline Source & Part and Uses & $\begin{array}{l}\text { Income } \\
\text { generation }\end{array}$ \\
\hline $\begin{array}{l}\text { Butea monosperma (Paras) } \\
\text { B. vahlii (Paras vel) }\end{array}$ & Leaf: Making plates & $\begin{array}{l}\text { Rs. } 12 /- \text { for } 100 \\
\text { leaves }\end{array}$ \\
\hline Diospyros melanoxylon (Tendu) & $\begin{array}{l}\text { Leaf: Beedi preparation } \\
\text { (like cigar) } \\
\text { Fruit: Jam preparation }\end{array}$ & $\begin{array}{l}\text { Rs.150/- for } 1000 \\
\text { leaves } \\
\text { Rs. 3/- per kg }\end{array}$ \\
\hline $\begin{array}{l}\text { Cassia tora (Tarota); } \\
\text { Tamerindus indicus (Chinch) }\end{array}$ & Leaf: Vegetable & Rs. 3/- per Kg \\
\hline Madhuca indica (Mohwa) & $\begin{array}{l}\text { Flower: alcoholic beverage and } \\
\text { sweetener } \\
\text { Seed: Extracting oil }\end{array}$ & $\begin{array}{l}\text { Rs. 9/- per } \mathrm{Kg} \\
\text { Rs. 4/- per Kg }\end{array}$ \\
\hline $\begin{array}{l}\text { Eugenia jambolina (Jamoon) } \\
\text { Buchanania lanzan (Charoli) } \\
\text { Phyllanthus emblica (Awda) } \\
\text { Zizyphus oenoplea (Aroni) } \\
\text { Z. jujuba (Bhor) } \\
\end{array}$ & Fruit: Making juices and pickles & Rs. 9/- per Kg \\
\hline $\begin{array}{l}\text { Terminalia bellerica } \text { (Behra) } \\
\text { T. chebula } \text { (Hirda) } \\
\text { Sesbania grandiflora } \text { (Heti) } \\
\text { Bauhinia purpurea } \text { (Raktakanchan) } \\
\text { Semecarpus anacardium } \text { (Bibba) }\end{array}$ & $\begin{array}{l}\text { Fruit and flower are used in the } \\
\text { preparation of local medicines and } \\
\text { also exports in pharmaceutical } \\
\text { industry }\end{array}$ & Rs. $15 /-$ per $\mathrm{Kg}$ \\
\hline $\begin{array}{l}\text { Boswelia serrata (Salai) } \\
\text { Lannaea coromandelina (Mahaiw) } \\
\text { Anogeisus latifolia (Dhawra) } \\
\text { Acacia nilotica (Babul) } \\
\text { Sterculia urens (Karai) } \\
\text { Gardenia resinifera (Dikamali) }\end{array}$ & $\begin{array}{l}\text { Extracting gum and using as } \\
\text { medicinal purpose }\end{array}$ & Personal utilization \\
\hline
\end{tabular}

Tab. 5 - Present and future status of the studied forests.

\begin{tabular}{llll}
\hline \multicolumn{1}{c}{ Forest } & \multicolumn{1}{c}{ Present status } & \multicolumn{1}{c}{ Future status } & \multicolumn{1}{c}{ Steps to be taken } \\
\hline Markegaon & $\begin{array}{l}\text { Good condition with more } \\
\text { number of trees but equal } \\
\text { number of seedlings and } \\
\text { saplings }\end{array}$ & Negative growth & $\begin{array}{l}\text { Management practices } \\
\text { required to create open } \\
\text { space by felling mature } \\
\text { or old trees and planta- } \\
\text { tions. }\end{array}$ \\
\hline Devulgaon & Good condition & $\begin{array}{l}\text { It will maintain } \\
\text { same status }\end{array}$ & $\begin{array}{l}\text { Maintain management } \\
\text { practices. }\end{array}$ \\
\hline Ranvahi & $\begin{array}{l}\text { Low level of seedlings and } \\
\text { saplings shows pressure of } \\
\text { grazing and other human } \\
\text { interferences }\end{array}$ & Negative growth & $\begin{array}{l}\text { Range management and } \\
\text { plantations }\end{array}$ \\
\hline
\end{tabular}




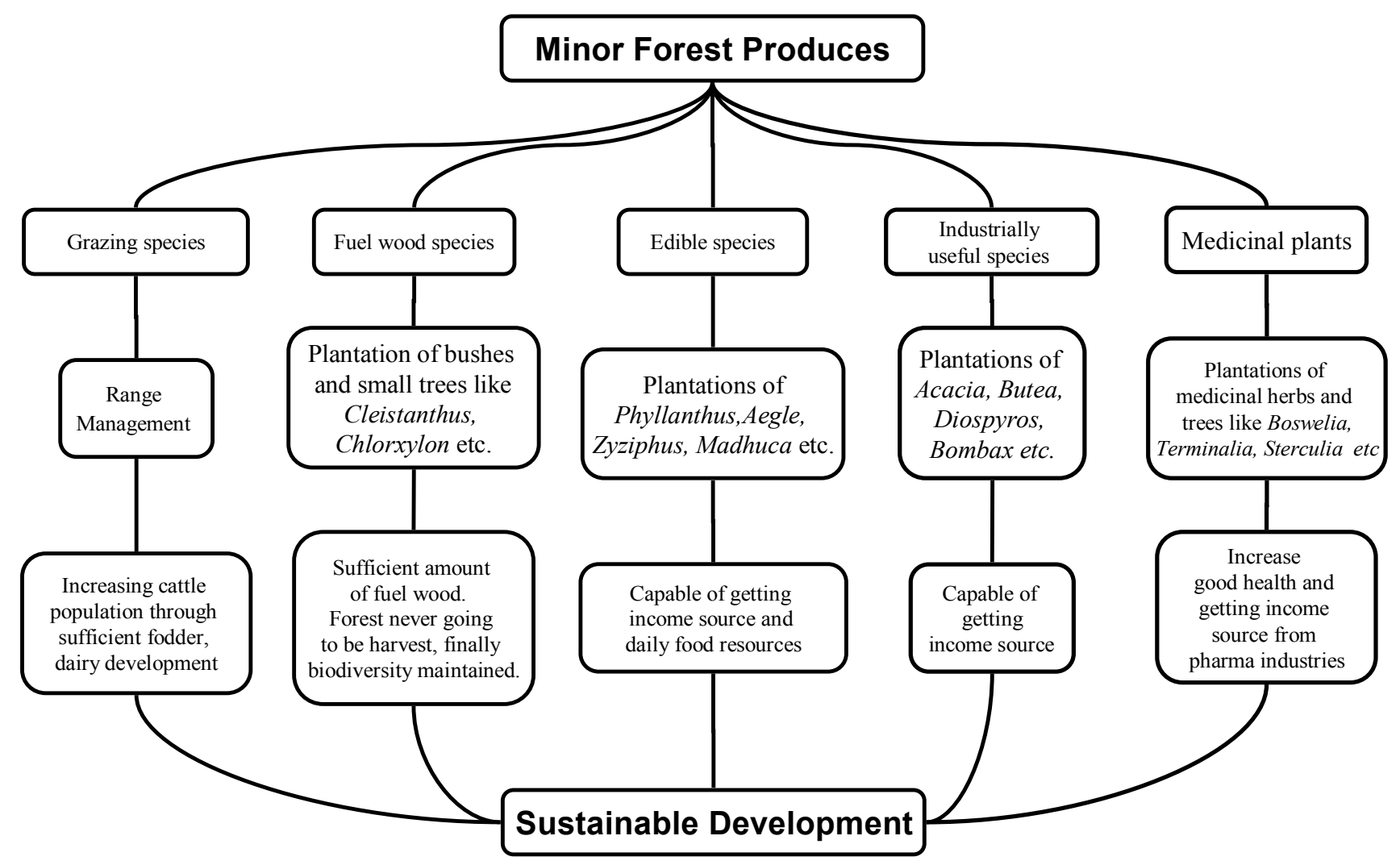

Fig. 4 - Resource management model for sustainable development.

of a natural and organized community (Little 1994). Leadership can be informal/traditional or formal, but a leader should have the capability to make the community beneficial (Hardin 1968). These efforts were supported by the forest department. Almost 15 years ago the community-initiated management has begun in Devulgaon. Effective leadership, which could convince everybody in the village about the need to protect forest resource, seems to have made a huge impact in the initial success of collective action and emergence of local institution. In addition to this, factors like self-imposed restrictions by the community, monitoring by the members within the community, effective patrolling, verifiable improvement in the quality of the resource, improved flow of forest goods like fuel and fodder have contributed to the effective working of the local institution in Devulgaon.

\section{Sustainable resource management model}

There is growing awareness that biodiversity is closely linked with long-term health and vigour of the biosphere, as an indicator of global environment and also as a regulator of ecosystem functioning (Solbrig 1991). The height and diameter (dbh) analysis revealed that these forests have a good source of carbon mitigation in future. Plant growth is directly proportional to the carbon sequestration capacity of the forest (Kumar 2008, Kumar et al. 2008). Present and future status of these forests is showed in Tab. 5. Knowledge on status of MFP's, their utility and dependences of natives on them forced us to think about the plans for their sustainable development. Problems of grazing species can be circumvented by range management plans, which includes introduction of grasses, sedges and small bushes in nearby villages. This type of management could help villagers in getting fuel wood without disturbing the main vegetation (McKean 2000). Plantation of fuel wood species and horticulturally important species could help to improve fuel production and fulfil daily requirement of food. Selection of the species should be such that recurring efforts for the plantation should not be needed. In the management of industrial valued species, harvesting time should be right and there should be replacement plan for harvested species. Medicinal plants are today's green gold, number of pharmaceutical companies are coming forward. Plantation of these species can help in regular supply of raw materials and such species would require more attention of conservation. A management model is drawn in Fig. 4 for the sustainable development of aboriginals through different groups of MFP's and their management practices.

\section{Conclusion}

The MFP's of the study area are fuel wood, species of horticultural importance, medicinal plants, fodder grasses, sedges and several species of ethno-botanical importance. This study suggests that locals are dependent on plants for their various needs. However, as seen in Ranvahi, the activities of inhabitants sometimes result in the negative growth of natural resources. The distribution of MFP's in these forests is characterized by random distribution with two main patterns of population structure. One is represented by greater proportion of individuals in seedling stage indicating suitability of habitat (Devulgaon). Another pattern indicates more individuals in intermediate girth classes, wherein disturbances prevent regeneration, subsequently decrease in number of seedlings (Markegaon and Ranvahi). If such trend continues for longer period, these species may vanish from this area in near future. Hence there is an urgent need of sustainable management practices along with MFP cultivation programmes. A well-defined integrated land-use policy practice should be followed for fulfilment of regular needs and sustainable development of aboriginals.

\section{Acknowledgements}

The authors are thankful to the members of Shodh an NGO at Nagpur and SANDEE (South Asian Network for Developmental 
Environment Economics), Nepal for giving us this opportunity. We are also grateful to officials and other staff of Forest Department for extending cooperation and support during the forest visits.

\section{References}

Appasamy PP (1993). Role of minor forest produces in a subsistence economy: the case of a joint forestry project in India. Economic Botany 47: 258-267.

Boot R, Gullison R (1995). Approaches to developing sustainable extraction system for tropical forest products. Ecological Applications 5 (4): 896-903. - doi: 10.2307/2269340

Chaturvedi A, Ghate R, Kumar P (2006). Land use decisions by locals affecting spatial biodiversity. In: "Advancing Frontiers of Ecological Researches in India" (Kandya AK, Asha G eds). pp. 143-160

Chaturvedi A, Kumar P (2005). Ethno-botanical observations in Pench National Park, Maharashtra, India. In: “Advances in Ethnobotany" (Das AP ed). Bisensingh Mahendrapal Singh Publisher, Dehradun, pp. 119-206.

Cooke T (1958). The Flora of the presidency of Bombay. Botanical Survey of India Press, Calcutta, India, vol. 1-2.

Curtis JT (1959). The vegetation of Wisconsin. An ordination of plant communities. Wisconsin Press, Madison, USA.

Dowdeswell E (1995). Global biodiversity assessment, UNEP, CUP, UK

Ghate R, Chaturvedi A, Phani Kumar G (2003). Community-based forest management and landuse planning: a case study from Maharashtra. Van Vigyan 41 (1-4): 115-130.

Hall P, Bawa K (1993). Methods to assess the impact of extraction of non-timber tropical forest products on plant populations. Economic Botany 47: 234-247.

Hardin G (1968). The tragedy of commons. Science 162 (1): 243-248
Hariston NG (1964). Studies on the organization of animal communities. Journal of Ecology 52: 527-539.

Hegde R, Suryaprakash S, Achoth L, Bawa KS (1996). Extraction of minor forest produces in the forests of Biligiri Rangan Hills, India, 1: contribution to rural income. Economic Botany 50: 243-251.

Hooker JD (1904). The flora of British India. Oxford Press, London, UK.

Howard AF (1993). A linear programming model for predicting the sustainable yield of timber from a community forest on the Osa Peninsula of Costa Rica. Forest Ecology Management 61: 2943. - doi: 10.1016/0378-1127(93)90188-S

IFRI (2002). Field manual (version 10.5). Workshop in political theory and policy analysis. International Forest Resources and Institutions (IFRI), Indiana University, Bloomington, USA.

Kalla JC (1988). Forestry and economic development. Indian Journal of Agricultural Economics 43: 237.

Kumar P (2008). Carbon sequestration strategy of Nubra Valley with special reference to agroforestry. DRDO Technology Spectrum, pp. 187192.

Kumar P, Gupta S, Prakash S (2008). Carbon pool of orchards in siachen sector: socio-economic carbon sequestration. In: "Advances in agriculture environment and health" (Singh SB, Charassia OP, Yadav S eds). pp. 225-233.

Lavorel S, Prieur-Richard AH, Grigulis K (1999). Invasibility and diversity of plant communities: from patterns to processes. Diversity Distribution 5: 41-49. - doi: 10.1046/j.1472-4642.1999. 00034.x

Little PD (1994). The link between local participation and improved conservation: a review of issues and experiences. In: "Natural connections: perspectives in community-based conservation" (Western D, Wright M eds). Island Press, Washington, DC, pp. 347-372.

Lynch OJ, Alcorn JB (1994). Tenurial rights and community-based conservation. In: "Natural connections: perspectives in community-based conservation" (Western D, Wright $\mathrm{M}$ eds). Island Press, Washington, DC, pp. 347-372.

McKean M (2000). Common property: what is it good for, and what makes it work? In: "People and forests - Communities, institutions and governance" (Gibson, McKean, Ostrom eds). pp. 27 56

McNeely JA (1988). Conserving the world's biological diversity. Global Biodiversity Assessment, UNEP, CUP, UK.

Misra R (1968). Ecology work book. Oxford and IBH Publ. Co., New Delhi, India.

Odum EP (1971). Fundamentals of ecology. WB Saunders Co., Philadelphia, PA, USA.

Phillips EA (1959). Methods of vegetation study. A Holt-dryden Book, Henry Holt and Co. Inc. New York, NY, USA.

Sekar C, Vinay Rai RS, Ramasamy C (1996) Role of minor forest products in tribal economy of India: a case study. Journal of Tropical Forest Science 8: 280-88.

Shannon CE, Wiener W (1963). The mathematical theory of communication. Univ. Illinois Press, Urbana, IL, USA.

Shiva MP, Mathur RB (1995). Management of minor forest produce for sustainability. New Delhi, India, Oxford, UK.

Simpson EH (1949). Measurement of diversity. Nature 163: 188. - doi: 10.1038/163688a0

Sinha A, Bawa KS (2002). Harvesting techniques, hemiparasites and fruit production in two nontimber forest tree species in south India. Forest Ecology and Management 168: 289-300. - doi 10.1016/S0378-1127(01)00747-2

Solbrig OT (1991). The origin and function of biodiversity. Environment 36: 16-20.

Ugemuge NR (1978). The flora of Nagpur district. Kalyani publications, New Delhi, India. 